ISSN 1392-3196 / e-ISSN 2335-8947

Zemdirbyste-Agriculture, vol. 108, No. 3 (2021), p. 195-202

DOI 10.13080/z-a.2021.108.025

\title{
The influence of long-term fertilisation on phosphorus dynamics in the soil
}

\author{
Jonas ARBAČAUSKAS, Aistė MASEVIČIENĖ, Gediminas STAUGAITIS, Lina ŽIČKIENĖ, \\ Donatas ŠUMSKIS, Zigmas VAIŠVILA
}

\author{
Lithuanian Research Centre for Agriculture and Forestry \\ Savanorių 287, Kaunas, Lithuania \\ E-mail: jonas.arbacauskas@lammc.lt
}

\begin{abstract}
A long-term experiment on agricultural plant fertilisation was carried out on a sandy loam Epicalcari-EndocalcariEndohypogleyic Luvisol in Central Lithuania from 1971 to 2019. The aim of the study was to determine the influence of long-term use of mineral phosphorus $(\mathrm{P})$ fertilisers and their interaction with nitrogen $(\mathrm{N})$ and potassium $(\mathrm{K})$ fertilisers on $\mathrm{P}$ fertiliser uptake, mobile phosphorus $\left(\mathrm{P}_{2} \mathrm{O}_{5}\right)$ concentration and $\mathrm{P}$ balance in the soil, and to evaluate its relationship with $\mathrm{P}$ leaching from sandy loam soils.

According to the data of the study, after 49 years different combinations of NPK fertilisers in the fertilised fields resulted in the variations of mobile $\mathrm{P}_{2} \mathrm{O}_{5}$ in the $0-20 \mathrm{~cm}$ soil layer: $62-71 \mathrm{mg} \mathrm{kg}^{-1}$ without $\mathrm{P}_{0}, 280-351 \mathrm{mg} \mathrm{kg}^{-1}$ with annual $\mathrm{P}_{95}$ fertilisation and 503-614 mg kg-1 with $\mathrm{P}_{190}$, or 10 times higher compared to zero $\mathrm{P}$ application. Due to fertilisation with $\mathrm{P}$, the total phosphorus $\left(\mathrm{P}_{\text {tot }}\right)$ concentration in the soil increased. The $\mathrm{P}$ balance showed that after 49 years of annual applications of $\mathrm{P}_{95}$ to agricultural crops, $45.4-68.7 \mathrm{~kg} \mathrm{ha}^{-1}$ was incorporated, and when $\mathrm{P}_{190}$ was applied, 131.0-160.3 $\mathrm{kg} \mathrm{ha}^{-1}$ was incorporated in excess of the need for this element by plants. The most inefficient uptake $5.4-11.4 \% \mathrm{P}$ was observed after annual application of $\mathrm{P}_{190}$ without the use of $\mathrm{N}$ and $\mathrm{K}$ fertilisers. The uptake increased to $27.3-32.6 \%$ when $\mathrm{N}_{216} \mathrm{~K}_{190}$ fertiliser was applied together with $\mathrm{P}_{95}$. With increasing rates of $\mathrm{P}$ fertilisers, $\mathrm{P}_{2} \mathrm{O}_{5}$ leaching from the soil 0-40 cm layer increased. Without $\mathrm{P}$ application, its annual leaching was as follows: in 1976-1998-0.43-0.77 $\mathrm{kg} \mathrm{ha}^{-1}$, in 1976-2019-0.82-0.90 $\mathrm{kg} \mathrm{ha}^{-1}$.

This study was able to establish significant relationships between P fertiliser uptake and NPK fertiliser rates, between mobile $\mathrm{P}_{2} \mathrm{O}_{5}$ concentration in the soil and $\mathrm{P}$ balance, and between $\mathrm{P}_{\text {tot }}$ concentration in the soil and $\mathrm{P}$ balance.
\end{abstract}

Key words: NPK fertilisation, balance, mobile phosphorus, leaching.

\section{Introduction}

Phosphorus (P) is one of the key elements influencing ecosystem sustainability and crop productivity (Johnston et al., 2014). More than 170 Pcontaining soil mineral types have been identified. However, $\mathrm{P}$ is very stable or insoluble in the soil, and only a very small amount of it is present in the soil solution. Phosphorus fertilisers are an important means of increasing crop yields in soils with low levels of plant available P (Vaišvila, 1996; Cordell et al., 2009; Johnston et al., 2014). Meanwhile, in the countries, where crop production is intensive, crops are often over-fertilised with $P$ resulting in the accumulation of large amounts of this element in the soil leading to its increased leaching (Barberis et al., 1995; Tóth et al., 2014). Inefficient use of $P$ fertilisers is becoming an increasing problem in Europe as well as a number of mobile $\mathrm{P}_{2} \mathrm{O}_{5}$ compounds enter water bodies, deteriorating their quality and causing eutrophication (Scholz et al., 2013; Withers et al., 2015).
Phosphorus losses from soils also depend on the type of soil, its texture as well as climatic conditions (Glaesner et al., 2013; Bergström et al., 2015). The efficient use of $\mathrm{P}$ fertilisers is also important for the fact that the raw materials for the production of these fertilisers are scarce around the world, and they are not renewable, which makes P fertilisers more expensive (Jordan-Meille et al., 2012; Schoumans et al., 2015).

To reduce leaching losses of $\mathrm{P}$ from the soil and to optimize uptake of this nutrient by plants, it is important to know the cycle of the turnover of $\mathrm{P}$ in the soil and the best fertilisation practices (Veneklaas et al., 2012; Tóth et al., 2014; Bergström et al., 2015). A strategy for the efficient use of P fertilisers must ensure good yields of agricultural crops with minimal negative impact on the environment. In addition, the most important factor for the sustainable use of $\mathrm{P}$ fertilisers is the analysis of mobile $\mathrm{P}_{2} \mathrm{O}_{5}$ concentration in the soil

Please use the following format when citing the article:

Arbačauskas J., Masevičienė A., Staugaitis G., Žičkienė L., Šumskis D., Vaišvila Z. 2021. The influence of long-term fertilisation on phosphorus dynamics in the soil. Zemdirbyste-Agriculture, 108 (3): 195-202. DOI 10.13080/z-a.2021.108.025 
(Benton, 2012; Johnston et al., 2014; Tóth et al., 2014; Braun et al., 2019). Phosphorus uptake by agricultural plants and fertiliser efficiency depend not only on the mobile $\mathrm{P}_{2} \mathrm{O}_{5}$ concentration in the soil, but also on its buffer capacity, acidity $(\mathrm{pH})$, solubility of $\mathrm{P}$ compounds, moisture, physical properties of soil (Benton, 2012) and on securing plant nutrition by other nutrients (Ågren et al., 2012). The evaluation of the above properties facilitates a more efficient use of $\mathrm{P}$ reserves in the soil and developing limitations on the use of P fertilisers (Johnston et al., 2014; Medinski et al., 2018).

In order to ensure a more efficient use of $\mathrm{P}$ fertilisers, recommendations for the fertilisation of agricultural crops for farmers are prepared to achieve the planned yields by minimising the leaching of $\mathrm{P}$ compounds from the soil (Tóth et al., 2014; Braun et al., 2019). Recommendations for the use of $P$ fertilisers in Europe are usually based on a two-step approach. The first step involves the determination of plant available $\mathrm{P}$ concentration in soil; the second step is the determination of the relationship between plant available P concentration in the soil and agricultural crop yield calculations based on the data from fertilisation field trials. The mobile $\mathrm{P}$ concentrations in the soil are usually divided into three groups: low, medium and high (and sometimes very high). Using the above data, the recommended rates of $\mathrm{P}$ fertiliser for agricultural crops is calculated. In some European countries (France, Italy, Switzerland and the Netherlands), recommendations for the use of $P$ fertilisers also take into account other soil properties such as soil texture, clay and organic matter content, soil acidity, carbonate content and soil type (Jordan-Meille et al., 2012).

Recommendations for $\mathrm{P}$ fertilisation of agricultural plants in Lithuania are prepared according to similar principles. The key element for such calculations is the concentration of plant available $\mathrm{P}$ in the soil, determined by the Egnér-Riehm-Domingo (AL) method. Soil type, texture and acidity are also taken into account. Phosphorus fertiliser rates for agricultural crops are adjusted considering the relationship between crop yields and plant available $P$ concentrations obtained from short-term crop fertilisation trials on soils with different properties (Vaišvila, 1996; Management of agroecosystem..., 2010).

On 20 May 2020, as an integral part of The European Green Deal (Communication..., 2019), the European Commission unveiled the From Farm to Fork (2020) and Biodiversity Strategies (Communication..., 2020) to stand for a fair, healthy and environmentallyfriendly food system, while protecting nature and reversing the degradation of ecosystems. From Farm to Fork and Biodiversity Strategies put forward ambitious targets to reduce nutrient losses by at least $50 \%$, while ensuring no deterioration in soil fertility. This is expected to result in $20 \%$ reduction of fertiliser use. These targets will require substantial changes in agricultural practices, while using fertilisers.

However, the influence of $\mathrm{P}$ fertilisers and their interaction with other plant nutrients on crop yield, soil $\mathrm{P}$ content and soil $\mathrm{P}$ leaching trends are best demonstrated by long-term crop fertilisation trials conducted under site-specific soil and climatic conditions (Blake et al., 2000; Buczko et al., 2018; Johnston, Poulton, 2018). The losses from leaching of biogenic elements are impacted not only by the fertilisation practices but also by climate conditions, especially by precipitation levels. Soil coverage by plants, humidity of soil and air temperature have an important impact as well (Arheimer el al., 2012; Thodsen at al., 2017; Kim et al., 2018).
A long-term experiment on agricultural plant fertilisation was carried out since 1971 on a sandy loam Luvisol in the Middle Lithuanian Lowland. The aim of the study was to determine the influence of long-term use of mineral phosphorus $(\mathrm{P})$ fertilisers and their interaction with nitrogen $(\mathrm{N})$ and potassium $(\mathrm{K})$ fertilisers on $\mathrm{P}$ fertiliser uptake, mobile phosphorus $\left(\mathrm{P}_{2} \mathrm{O}_{5}\right)$ concentration and $\mathrm{P}$ balance in the soil, and to evaluate its relationship with $\mathrm{P}$ leaching from sandy loam soil.

\section{Materials and methods}

$\left.23^{\circ} 74^{\prime} 97.6^{\prime \prime} \mathrm{E}\right)$, Radviliškis distr., Lithuania, on a sandy loam Epicalcari-Endocalcari-Endohypogleyic Luvisol (WRB, 2015). Before the start of the experiment (1971), in the soil arable $(0-20 \mathrm{~cm})$ layer, $\mathrm{pH}_{\mathrm{KCl}}$ was 6.9 \pm 0.22 , humus content $-2.2 \pm 0.32 \%$, total nitrogen $\left(\mathrm{N}_{\text {tot }}\right)$ $-0.17 \pm 0.03 \%$, total phosphorus $\left(\mathrm{P}_{\text {to }}\right)-0.301 \pm 0.043 \%$, mobile phosphorus $\left(\mathrm{P}_{2} \mathrm{O}_{5}\right)-64 \pm 11.4 \mathrm{mg} \mathrm{kg}^{-1}$ and mobile potassium $\left(\mathrm{K}_{2} \mathrm{O}\right)-96 \pm 12.0 \mathrm{mg} \mathrm{kg}{ }^{-1}$. Perennial grasses, winter wheat, spring rapeseed, annual grasses, spring barley and sugar beets were grown according to the crop rotation in the experimental area. The article presents data on the calculation of $\mathrm{P}$ in the soil, its uptake and balance for 1971-1986, 1971-1998 and 1971-2019 experimental periods, i.e., for 16, 28 and 49 years. Concentrations of $P_{\text {tot }}$ and mobile $\mathrm{P}_{2} \mathrm{O}_{5}$ were determined in the topsoil $0-20 \mathrm{~cm}$. Phosphorus leaching was determined in the $0-40 \mathrm{~cm}$ layer starting from 1976.

Experimental design. The experiment was carried out according to the research design based on several factors compiled by Перегудов и др. (1976). The experimental design includes 27 treatments (Table 2). The scheme indicates the average annual fertilisation $\left(\mathrm{kg} \mathrm{ha}^{-1}\right)$ by $\mathrm{N}, \mathrm{P}_{2} \mathrm{O}_{5}$ and $\mathrm{K}_{2} \mathrm{O}$, respectively: $\mathrm{N}_{0}, \mathrm{~N}_{108}, \mathrm{~N}_{216} ; \mathrm{P}_{0}, \mathrm{P}_{95}$, $\mathrm{P}_{190} ; \mathrm{K}_{0}, \mathrm{~K}_{95}, \mathrm{~K}_{190}$. The experimental plot size was $6 \times 9 \mathrm{~m}$, each treatment was repeated twice. To fertilise agricultural plants throughout the experimental years, ammonium nitrate $(34.4 \% \mathrm{~N})$, granulated superphosphate $\left(19 \% \mathrm{P}_{2} \mathrm{O}_{5}\right)$ and crystal potassium chloride $(\mathrm{KCl})\left(60.0 \% \mathrm{~K}_{2} \mathrm{O}\right)$ were used. Before sowing, fertiliser was spread manually and incorporated into the soil using a cultivator.

Experimental methods. The $\mathrm{P}_{2} \mathrm{O}_{5}$ concentration in the soil was determined by the Egnér-Riehm-Domingo (A-L) method. Other soil analyses were performed by using the following methods: soil $\mathrm{pH}_{\mathrm{KCl}}-$ in $1 \mathrm{M} \mathrm{KCl}$ (extraction ratio 1:5) by the potentiometric method; humus - by the dry combustion method using a carbon analyser "liquiTOC II" (Elementar Analysensysteme GmbH, Germany); $\mathrm{N}_{\text {tot }}$ - by the Kjeldahl method; mobile $\mathrm{K}_{2} \mathrm{O}$ - by the (A-L) method; $\mathrm{P}_{\text {tot }}$ - by mineralising the soil using a royal acid solution $\left(\mathrm{HNO}_{3}\right.$ and $\mathrm{HCl}$ mixture at $1: 3$ ratio) followed by the colorimetric method.

The $\mathrm{P}$ content in lysimeter leachates was determined by the colorimetric method after acidification and colouring the water with ammonium molybdate. The $\mathrm{P}$ content in plants was determined by combusting plant material in a muffle furnace at $550^{\circ} \mathrm{C}$ temperature, dissolving ash in $\mathrm{HNO}_{3}$ and $\mathrm{HCl}$ acids and diluting with water by the colorimetric method. The $\mathrm{P}$ balance (B) in the soil was calculated using the difference between the amount of $\mathrm{P}$ added with the fertiliser $(\mathrm{T})$ and the amount of $\mathrm{P}$ accumulated in the crop (D): B $\left(\mathrm{kg} \mathrm{ha}^{-1}\right)=\mathrm{T}-\mathrm{D}$. Phosphorus uptake from fertilisers was calculated by the difference method most commonly used in field experiments (Syers et al., 2008). This is the ratio of the amounts of $\mathrm{P}$ stored in the yield increase $\left(\mathrm{P}_{\mathrm{p}}\right)$ to that added as fertiliser $\left(\mathrm{P}_{t}\right)$, expressed as a percentage: $\mathrm{P}(\%)=\mathrm{P}_{\mathrm{p}} /$ $P_{t} \times 100$. The higher the value (\%) obtained, the higher 
the uptake of $\mathrm{P}$ fertilisers and the lower the probability that unabsorbed $\mathrm{P}$ from plants will be fixed in the soil in forms inaccessible to plants or leach into water bodies.

The measurements of $\mathrm{P}$ leaching from the soil were performed using Шилова (1955) lysimeters. They were buried to a depth of $40 \mathrm{~cm}$ in the soil in nine application plots $-\mathrm{N}_{0} \mathrm{P}_{0} \mathrm{~K}_{0}, \mathrm{~N}_{0} \mathrm{P}_{95} \mathrm{~K}_{95}, \mathrm{~N}_{0} \mathrm{P}_{190} \mathrm{~K}_{190}$, $\mathrm{N}_{108} \mathrm{P}_{95} \mathrm{~K}_{0}, \mathrm{~N}_{108} \mathrm{P}_{0} \mathrm{~K}_{95}, \mathrm{~N}_{108} \mathrm{P}_{95}^{0} \mathrm{~K}_{95}^{0}, \mathrm{~N}_{216}^{0} \mathrm{P}_{0} \mathrm{~K}_{190}, \mathrm{~N}_{216}{ }_{190}{ }_{190} \mathrm{~K}_{0}$ and $\mathrm{N}_{216} \mathrm{P}_{190} \mathrm{~K}_{190}$. The lysimeter screen size was $40 \times 57$ $\mathrm{cm}$, a receiver capacity -3 litres. Lysimeter water samples were taken in spring before fertilisation (April-May) and in autumn after harvesting (October-November). Soil samples were collected once in four years, at the end of crop rotation. Crop yield samples were collected each year from two replications of all treatments of the experiment.
The amount of phosphate $\left(\mathrm{kg} \mathrm{ha}^{-1}\right)$ leached from the soil was calculated by multiplying the average annual phosphate $\left(\mathrm{PO}_{4}^{3-}\right)$ concentration in lysimeter leachates by the annual precipitation $\left(\mathrm{m}^{3} \mathrm{ha}^{-1}\right)$ and the leaching rate, which is 0.34 in light loam soils of the Middle Lithuanian Lowland (Baigys, Gaigalis, 2012). The obtained $\mathrm{PO}_{4}^{3-}$ amount in $\mathrm{kg} \mathrm{ha}^{-1}$ was converted to $\mathrm{P}_{2} \mathrm{O}_{5}$.

Meterological conditions. The average air temperature and precipitation by individual experimental periods are presented in Table 1. These data show global warming since the average air temperature 1971-1990, 1991-2005 and 2006-2020 was $0.5 ; 1.0$ and even $1.8^{\circ} \mathrm{C}$ higher than the multi-year rate. During the 2006-2020 experimental period, the average annual precipitation exceeded the multi-annual precipitation rate $(566 \mathrm{~mm})$. During the 1971-1990 and 1991-2005 experimental

Table 1. Meterological conditions (Skėmiai, Radviliškis distr., 1971-2020)

\begin{tabular}{|c|c|c|c|c|c|c|c|c|}
\hline \multirow[b]{2}{*}{ Month } & \multicolumn{4}{|c|}{ Temperature ${ }^{\circ} \mathrm{C}$} & \multicolumn{4}{|c|}{ Precipitation $\mathrm{mm}$} \\
\hline & $\begin{array}{c}1971- \\
1990\end{array}$ & $\begin{array}{l}1991- \\
2005\end{array}$ & $\begin{array}{c}2006- \\
2019\end{array}$ & $\begin{array}{l}\text { Multi- } \\
\text { annual } \\
\text { average }\end{array}$ & $\begin{array}{c}1971- \\
1990\end{array}$ & $\begin{array}{l}1991- \\
2005\end{array}$ & $\begin{array}{c}2006- \\
2020\end{array}$ & $\begin{array}{c}\text { Multi-annual } \\
\text { average }\end{array}$ \\
\hline January & -4.9 & -2.8 & -4.1 & -5.4 & 39 & 31 & 46 & 34 \\
\hline February & -3.3 & -2.6 & -3.1 & -4.5 & 26 & 33 & 29 & 25 \\
\hline March & 0.1 & 0.5 & 1.1 & -2.6 & 31 & 31 & 29 & 32 \\
\hline April & 5.9 & 7.0 & 7.6 & 5.6 & 38 & 30 & 34 & 40 \\
\hline May & 12.4 & 12.3 & 12.9 & 12.3 & 48 & 44 & 49 & 36 \\
\hline June & 15.5 & 15.5 & 16.7 & 15.8 & 64 & 58 & 47 & 62 \\
\hline July & 16.9 & 17.9 & 18.8 & 17.0 & 81 & 68 & 92 & 70 \\
\hline August & 16.0 & 17.3 & 18.0 & 16.4 & 64 & 59 & $7 \overline{7}$ & 67 \\
\hline September & 11.9 & 12.7 & 13.4 & 11.8 & 49 & 45 & 51 & 54 \\
\hline October & 6.7 & 6.9 & 7.4 & 6.9 & 48 & 49 & 51 & 47 \\
\hline November & 1.8 & 1.6 & 4.0 & 1.7 & 48 & 40 & 50 & 55 \\
\hline December & -1.5 & -1.8 & 0.6 & -2.5 & 48 & 41 & 48 & 44 \\
\hline \multicolumn{5}{|c|}{ Average annual air temperature ${ }^{\circ} \mathrm{C}$} & \multicolumn{4}{|c|}{ Average annual amount of precipitation $\mathrm{mm}$} \\
\hline & 6.5 & 7.0 & 7.8 & 6.0 & 585 & 529 & 602 & 566 \\
\hline
\end{tabular}

periods, its levels were close to the multi-annual norm (585 and $529 \mathrm{~mm}$, respectively).

Statistical analysis. Statistical significance of the experimental data was assessed using Duncan's multiple range test; significant differences were established between the data lettered a, b, c, d, e, f, etc. at $5 \%$ probability level $(P \leq 0.05)$ (Raudonius, 2017). Mean and their ratios as well as standard deviations (SD) were calculated using software Excel (Microsoft, USA). To determine the strength and nature of the relationship between the variables, correlation and regression data analysis was performed using software Statistica, version 7 (Hill, Levicki, 2005).

\section{Results and discussion}

Uptake of phosphorus (P) fertilisers. According to the performed experiment, the uptake of $\mathrm{P}$ fertilisers depended mainly on the rates of these fertilisers as well as on the fertilisation with $\mathrm{N}$ and $\mathrm{K}$ fertilisers (Table 2).
During the experimental period, $\mathrm{P}$ was best absorbed from mineral fertilisers by agricultural plants (up to $32.6 \%$ ) after fertilising with $\mathrm{P}_{95}$ on average annually together with $\mathrm{N}_{108}$ and $\mathrm{N}_{216}$ and $\mathrm{K}_{95}$ and $\mathrm{K}_{190}$ fertilisers. Assessing the results from an ecological point of view and in order to ensure soil sustainability, the most optimal fertiliser combination for $\mathrm{P}$ uptake from fertiliser was $\mathrm{N}_{108} \mathrm{P}_{95} \mathrm{~K}_{95}$. The uptake of $\mathrm{P}$ fertilisers decreased significantly with agricultural crops being fertilised at significantly higher rates $\left(\mathrm{P}_{190}\right)$ than those required to ensure optimal plant nutrition. In addition, the uptake of $P$ fertilisers decreased significantly throughout the experimental period without fertilisation with Kand especially $\mathrm{N}$ fertilisers for a prolonged period. During the 1971-1986, 1971-1998 and 1971-2019 experimental periods, having had the average annual fertilisation rate of only $\mathrm{P}_{10} \mathrm{~kg}$ $\mathrm{ha}^{-1}$, agricultural plants assimilated $11.4,9.5$ and $7.6 \%$ of $\mathrm{P}$ fertilisers, respectively. As the experimental period lengthened, fertilisation, especially that with higher $\left(\mathrm{N}_{216}\right.$ and $\mathrm{P}_{190}$ ) fertiliser rates, resulted in high $\mathrm{P}$ concentration

Table 2. Uptake of phosphorus $\left(\mathrm{P}_{2} \mathrm{O}_{5}\right)$ fertilisers depending on the fertilisation intensity

\begin{tabular}{|c|c|c|c|c|}
\hline \multirow{5}{*}{$\mathrm{N}$} & \multirow{5}{*}{$\mathrm{P}_{2} \mathrm{O}_{5}$} & \multicolumn{3}{|c|}{ Average annual fertiliser rate $\mathrm{kg} \mathrm{ha}^{-1}$} \\
\hline & & \multicolumn{3}{|c|}{$\mathrm{K}_{2} \mathrm{O}$} \\
\hline & & $\begin{array}{c}0 \\
\end{array}$ & 95 & 190 \\
\hline & & $\begin{array}{c}\text { Experimental periods: } \\
1971-1986,1971-1998 \text { and } 1971-2019\end{array}$ & & \\
\hline & & Uptake of $\mathrm{P}$ fertilisers $\%$ & & \\
\hline 0 & $\begin{array}{c}0 \\
95 \\
190 \\
\end{array}$ & $\begin{array}{c}14.2 / 12.3 / 11.6 \\
11.4 / 9.5 / 7.6\end{array}$ & $\begin{array}{c}12.1 / 10.2 / 13.0 \\
8.9 / 7.0 / 7.4\end{array}$ & $\begin{array}{c}18.9 / 13.6 / 14.0 \\
7.5 / 6.7 / 7.5\end{array}$ \\
\hline 108 & $\begin{array}{c}0 \\
95 \\
190\end{array}$ & $\begin{array}{c}20.9 / 21.4 / 15.6 \\
11.6 / 12.1 / 9.7\end{array}$ & $\begin{array}{l}28.0 / 30.6 / 25.2 \\
18.5 / 19.4 / 15.0\end{array}$ & $\begin{array}{l}21.4 / 24.3 / 22.9 \\
13.4 / 16.2 / 15.6\end{array}$ \\
\hline 216 & $\begin{array}{c}0 \\
95 \\
190 \\
\end{array}$ & $\begin{array}{l}14.6 / \overline{14} .7 / 7.0 \\
11.5 / 11.9 / 7.4\end{array}$ & $\begin{array}{l}22.5 / 2 \overline{6} .1 / 17.3 \\
15.2 / 16.8 / 12.4\end{array}$ & $\begin{array}{l}30.8 / 32.6 / 19.6 \\
19.5 / 20.1 / 14.6\end{array}$ \\
\hline
\end{tabular}


in the soil, which reduced the influence of $\mathrm{P}$ fertiliser rates on the uptake of these fertilisers.

To reduce $\mathrm{P}$ loss from soil and optimise the uptake of this plant nutrient, it is important to know about $\mathrm{P}$ metabolism in soil and best practices for $\mathrm{P}$ fertilisation (Veneklaas et al., 2012; Tóth et al., 2014; Bergström et al., 2015). Plants are reported to absorb $20-30 \%$ of $\mathrm{P}$ from fertilisers with the remainder chemically sorbed, biologically immobilised and leached (López-Arredondo et al., 2014). In addition, $P$ uptake from fertilisers and soil also depends on plant nutrition with other essential nutrients and other conditions (Johnston et al., 2014).

During individual experimental periods, a very strong and significant dependence $(r=0.95-0.96$, $P<0.01)$ of the $\mathrm{P}$ fertiliser uptake $(y, \%)$ on the rates of NPK fertilisers and their interaction $\left(x, \mathrm{kgha}^{-1}\right)$ was observed (Table 3). However, the analysis of individual parameters of the regression equation showed that such significant dependence of the $\mathrm{P}$ fertiliser uptake was only observed on the $\mathrm{P}$ rates $\left(\mathrm{a}_{2}\right)$, and to a lesser extent but also significantly - on those of $\mathrm{N}$ fertilisers $\left(\mathrm{a}_{1}\right)$. As the rates of $P$ fertilisers increased, the uptake of $P$ fertilisers decreased steadily $\left(\mathrm{a}_{5}\right)$. The interactions between $\mathrm{N}$ and $\mathrm{P}\left(\mathrm{a}_{7}\right), \mathrm{N}$ and $\mathrm{K}\left(\mathrm{a}_{8}\right)$ as well as those between $\mathrm{P}$ and $\mathrm{K}$ $\left(a_{9}\right)$ fertilisers had a positive effect on the uptake of $P$ fertilisers.

According to long-term crop fertilisation experiments in the UK, Germany and Poland, the effects of $\mathrm{P}$ fertilisers on crop yield and $\mathrm{P}$ balance are greater when other essential nutrients are sufficient in their nutrition (Blake et al., 2000).

Table 3. Dependence of phosphorus $\left(\mathrm{P}_{2} \mathrm{O}_{5}\right)$ fertiliser uptake on mineral NPK fertiliser rates

\begin{tabular}{|c|c|c|c|c|c|c|c|c|c|c|}
\hline \multicolumn{10}{|c|}{$\begin{array}{c}y=\mathrm{a}_{0}+\mathrm{a}_{1} \mathrm{~N}+\mathrm{a}_{2} \mathrm{P}+\mathrm{a}_{3} \mathrm{~K}+\mathrm{a}_{4} \mathrm{~N}^{2}+\mathrm{a}_{5} \mathrm{P}^{2}+\mathrm{a}_{6} \mathrm{~K}^{2}+\mathrm{a}_{7} \mathrm{NP}+\mathrm{a}_{8} \mathrm{NK}+\mathrm{a}_{9} \mathrm{PK} \\
\text { coefficient values }\end{array}$} & \multirow[t]{2}{*}{$R^{2}$} \\
\hline $\mathrm{a}_{0}$ & $a_{1}$ & $\mathrm{a}_{2}$ & $\mathrm{a}_{3}$ & $\mathrm{a}_{4}$ & $\mathrm{a}_{5}$ & $\mathrm{a}_{6}$ & $a_{7}$ & $a_{8}$ & $\mathrm{a}_{9}$ & \\
\hline \multicolumn{11}{|c|}{ 1971-1986 } \\
\hline-0.85 & 0.031 & 0.34 & 0.0075 & -0.00019 & -0.0015 & -0.00009 & 0.00015 & 0.00019 & 0.000054 & $0.91 * *$ \\
\hline \multicolumn{11}{|c|}{ 1971-1998 } \\
\hline-1.72 & 0.06 & 0.33 & 0.015 & -0.00032 & -0.0015 & -0.00015 & 0.00021 & 0.00022 & 0.000088 & $0.90^{* *}$ \\
\hline \multicolumn{11}{|c|}{ 1971-2019 } \\
\hline-1.16 & 0.057 & 0.26 & 0.026 & -0.00033 & -0.0012 & -0.00017 & 0.000097 & 0.00014 & 0.00012 & $0.92 * *$ \\
\hline
\end{tabular}

$R^{2}$ - coefficient of determination; * and ** - significant at the $P<0.05$ and $P<0.01$ probability levels; $\mathrm{a}_{0}-$ free member, $\mathrm{a}_{1}-\mathrm{a}_{9}$ NPK fertilisers and their interaction coefficients

Mobile phosphorus $\left(\mathrm{P}_{2} \mathrm{O}_{5}\right)$ concentration and balance in the soil. According to the performed experiment, the average annual $\mathrm{P}$ balance in the fields fertilised with $\mathrm{P}$ fertilisers was positive (Table 4). Having fertilised agricultural crops with $\mathrm{P}_{95} \mathrm{~kg} \mathrm{ha}^{-1}$ annually for 49 years, $45.4-68.7 \mathrm{~kg} \mathrm{ha}^{-1}$ of this plant nutrient was applied with fertilisers, and with $\mathrm{P}_{190}$ - actually, 131.0 $160.3 \mathrm{~kg} \mathrm{ha}^{-1}$ was applied in excess compared to the amount accumulated in the crop yield. In the plots not fertilised with $\mathrm{P}$ fertilisers, the $\mathrm{P}$ balance was negative and agricultural plants absorbed an average of 15.6$31.3 \mathrm{~kg} \mathrm{ha}^{-1} \mathrm{P}$ from the soil annually. Similar trends in $\mathrm{P}$

Table 4. Influence of nitrogen $(\mathrm{N})$, phosphorus $\left(\mathrm{P}_{2} \mathrm{O}_{5}\right)$ and potassium $\left(\mathrm{K}_{2} \mathrm{O}\right)$ fertiliser rates on the average annual $\mathrm{P}$ balance and mobile $\mathrm{P}_{2} \mathrm{O}_{5}$ concentration in the soil during different experimental periods

\begin{tabular}{|c|c|c|c|c|c|c|c|c|}
\hline \multicolumn{3}{|c|}{$\begin{array}{l}\text { Average annual fertiliser rate } \\
\qquad \mathrm{kg} \mathrm{ha}^{-1}\end{array}$} & \multicolumn{3}{|c|}{$\begin{array}{l}\text { Average annual P balance } \\
\qquad \mathrm{kg} \mathrm{ha}^{-1}\end{array}$} & \multicolumn{3}{|c|}{$\begin{array}{l}\text { Mobile } \mathrm{P}_{2} \mathrm{O}_{5} \text { concentration } \\
\text { in } 0-20 \mathrm{~cm}^{2} \text { soil layer }{ }^{1} \mathrm{mg} \mathrm{kg}^{-1}\end{array}$} \\
\hline $\mathrm{N}$ & $\mathrm{P}_{2} \mathrm{O}_{5}$ & $\mathrm{~K}_{2} \mathrm{O}$ & 1971-1986 & 1971-1998 & 1971-2019 & 1986 & 1998 & 2019 \\
\hline 0 & 0 & 0 & -23.8 & -18.5 & -15.6 & $69 a b c$ & $55 \mathrm{a}$ & $64 a$ \\
\hline 0 & 0 & 95 & -29.9 & -23.6 & -20.4 & $92 \mathrm{bc}$ & $50 \mathrm{a}$ & $62 \mathrm{a}$ \\
\hline 0 & 0 & 190 & -30.0 & -23.5 & -20.5 & $78 \mathrm{abc}$ & $63 \mathrm{a}$ & $67 \mathrm{a}$ \\
\hline 0 & 95 & 0 & 65.4 & 65.7 & 68.7 & $265 \mathrm{i}$ & $324 \mathrm{e}$ & $351 \mathrm{e}$ \\
\hline 0 & 95 & 95 & 61.5 & 62.6 & 67.3 & $186 \mathrm{def}$ & 283 cde & $335 \mathrm{de}$ \\
\hline 0 & 95 & 190 & 54.3 & 58.8 & 66.4 & $224 \mathrm{gh}$ & $297 \mathrm{de}$ & $352 \mathrm{e}$ \\
\hline 0 & 190 & 0 & 160.6 & 155.2 & 159.9 & $437 \mathrm{p}$ & $627 \mathrm{j}$ & $591 \mathrm{ghi}$ \\
\hline 0 & 190 & 95 & 159.5 & 155.0 & 160.3 & $224 \mathrm{gh}$ & $536 \mathrm{gh}$ & $579 \mathrm{fg}$ \\
\hline 0 & 190 & 190 & 162.3 & 155.5 & 160.1 & $341 \mathrm{kl}$ & $629 j$ & $614 \mathrm{i}$ \\
\hline 108 & 0 & 0 & -29.7 & -25.8 & -22.4 & $71 \mathrm{abc}$ & $57 \mathrm{a}$ & $71 \mathrm{a}$ \\
\hline 108 & 0 & 95 & -31.0 & -26.4 & -22.7 & $62 \mathrm{ab}$ & $56 \mathrm{a}$ & $64 \mathrm{a}$ \\
\hline 108 & 0 & 190 & -36.1 & -34.4 & -27.4 & $79 a b c$ & $53 \mathrm{a}$ & $63 \mathrm{a}$ \\
\hline 108 & 95 & 0 & 52.6 & 49.6 & 58.1 & $182 \mathrm{def}$ & $282 \mathrm{cde}$ & $321 \mathrm{cde}$ \\
\hline 108 & 95 & 95 & 44.0 & 40.6 & 48.9 & $244 \mathrm{hi}$ & $264 \mathrm{~cd}$ & $327 \mathrm{cde}$ \\
\hline 108 & 95 & 190 & 45.7 & 41.3 & 51.1 & $190 \mathrm{efg}$ & $243 \mathrm{bc}$ & $295 \mathrm{bc}$ \\
\hline 108 & 190 & 0 & 154.3 & 142.9 & 149.1 & $360 \mathrm{~lm}$ & $575 \mathrm{~h}$ & $578 \mathrm{fg}$ \\
\hline 108 & 190 & 95 & 138.5 & 128.0 & 139.0 & 410 nop & $533 \mathrm{gh}$ & $581 \mathrm{fgh}$ \\
\hline 108 & 190 & 190 & 144.0 & 129.5 & 138.0 & $303 j$ & $520 \mathrm{fg}$ & $579 \mathrm{fg}$ \\
\hline 216 & 0 & 0 & -35.1 & -32.2 & -31.3 & $99 \mathrm{c}$ & $53 \mathrm{a}$ & $62 a$ \\
\hline 216 & 0 & 95 & -37.3 & -33.3 & -30.9 & $63 \mathrm{ab}$ & $59 \mathrm{a}$ & $64 \mathrm{a}$ \\
\hline 216 & 0 & 190 & -33.7 & -28.6 & -25.9 & $58 \mathrm{a}$ & $58 \mathrm{a}$ & $63 \mathrm{a}$ \\
\hline 216 & 95 & 0 & 53.6 & 49.7 & 57.3 & $164 \mathrm{de}$ & $210 \mathrm{~b}$ & $302 \mathrm{bcd}$ \\
\hline 216 & 95 & 95 & 43.3 & 37.7 & 47.6 & $151 \mathrm{~d}$ & $215 b$ & $322 \mathrm{cde}$ \\
\hline 216 & 95 & 190 & 38.3 & 36.2 & 45.4 & $201 \mathrm{fg}$ & $214 \mathrm{~b}$ & $280 \mathrm{~b}$ \\
\hline 216 & 190 & 0 & 148.9 & 137.0 & 144.6 & $307 \mathrm{jk}$ & $478 \mathrm{f}$ & $503 \mathrm{j}$ \\
\hline 216 & 190 & 95 & 139.1 & 126.5 & 135.2 & $308 \mathrm{jk}$ & $420 \mathrm{f}$ & $551 \mathrm{f}$ \\
\hline 216 & 190 & 190 & 133.8 & 124.8 & 131.0 & $387 \mathrm{mn}$ & $484 \mathrm{f}$ & $554 \mathrm{f}$ \\
\hline
\end{tabular}

Note. ${ }^{1}$ - in 1971, before the start of the experiment, the average mobile $\mathrm{P}_{2} \mathrm{O}_{5}$ content in the $0-20 \mathrm{~cm}$ soil layer was $64 \pm 11 \mathrm{mg} \mathrm{kg}^{-1}$; different letters (a, b, c, etc.) indicate significant differences between the compared experimental applications at $P \leq 0.05$. 
balance were found in both 1971-1986 and 1971-1998 experimental periods.

Both the $\mathrm{P}$ balance and variations in the mobile $\mathrm{P}_{2} \mathrm{O}_{5}$ concentration in the soil depended on $\mathrm{P}$ fertiliser rates. The average annual application of $\mathrm{N}_{108} \mathrm{P}_{95} \mathrm{~K}_{95}$ fertiliser for agricultural crops in 1986, 1998 and 2019 resulted in 244, 264 and $327 \mathrm{mg} \mathrm{kg}^{-1}$ mobile $\mathrm{P}_{2} \mathrm{O}_{5}$ found in the $0-20 \mathrm{~cm}$ soil layer, respectively. Meanwhile, having fertilised the plants with twice the rates of the $\mathrm{N}_{216} \mathrm{P}_{190} \mathrm{~K}_{190}$ fertilisers annually, the mobile $\mathrm{P}_{2} \mathrm{O}_{5}$ concentrations in the $0-20 \mathrm{~cm}$ soil layer were 387,484 and $554 \mathrm{mg} \mathrm{kg}^{-1}$, respectively. Fertilisation with $\mathrm{P}$ fertilisers for the first 15 years had the greatest impact on the concentration of mobile $\mathrm{P}_{2} \mathrm{O}_{5}$ in the soil. In the following years, when higher levels of mobile $\mathrm{P}_{2} \mathrm{O}_{5}$ had accumulated in the soil, the influence of fertilisation on its variations in the soil was smaller. This means that in the presence of excess $\mathrm{P}$ balance, the $\mathrm{P}$ unabsorbed by plants accumulated in the soil and, when the concentration limit of about $300 \mathrm{mg} \mathrm{kg}^{-1}$ was reached, its accumulation in the soil slowed down due to leaching and chemical sorption.
In order to determine a long-term strategy for the use of $\mathrm{P}$ fertilisers, it is important to evaluate the changes in mobile $\mathrm{P}_{2} \mathrm{O}_{5}$ concentration in the soil and the accumulation of this element in agricultural crops (Johnston et al., 2014). According to Ekholm et al. (2005), the key tool for evaluation of $\mathrm{P}$ content changes and its leaching is the calculation of the $\mathrm{P}$ balance in the soil. Based on long-term experiments of fertilisation of agricultural plants in the UK, Germany and Poland, it was concluded that the impact of $\mathrm{P}$ fertilisers on overall $\mathrm{P}$ balance depends not only on $\mathrm{P}$ fertilisation practices but also on the concentration of other macro-nutrients in the soil (Blake et al., 2000; Johnston et al., 2014).

According to the data of the statistical analysis, the variation of mobile $\mathrm{P}_{2} \mathrm{O}_{5}$ concentration $\left(y ; \mathrm{mg} \mathrm{kg}^{-1}\right)$ depending on its balance $\left(x ; \mathrm{kg} \mathrm{ha}^{-1}\right)$ in the soil was described by a second-degree polynomial equation (Table 5 ). The quadratic dependence between the above indicators was very strong and significant during all years of the experiment: in $1971-1986-r=0.91$, and in 1971-1998 and 1971-2019 $-r=0.99$ at the $P<0.01$ probability level.

Table 5. Dependence of mobile phosphorus $\left(\mathrm{P}_{2} \mathrm{O}_{5}\right)$ concentration on the balance of this element in the soil (1971-2019)

\begin{tabular}{|c|c|c|c|c|c|c|}
\hline \multirow{2}{*}{$y$} & \multirow[t]{2}{*}{$x$} & \multirow{2}{*}{$\begin{array}{l}\text { Experimental } \\
\text { period }\end{array}$} & \multicolumn{3}{|c|}{$\begin{array}{c}\text { Parameters of equation } \\
y=\mathrm{a}+\mathrm{b} x+\mathrm{c} x^{2}\end{array}$} & \multirow[t]{2}{*}{$R^{2}$} \\
\hline & & & $\mathrm{a}$ & $\mathrm{b}$ & $\mathrm{c}$ & \\
\hline \multirow[t]{3}{*}{$\begin{array}{l}\text { Mobile } \mathrm{P}_{2} \mathrm{O}_{5} \\
\text { concentration } \\
\text { in soil } \mathrm{mg} \mathrm{kg}^{-1} \\
\end{array}$} & $\begin{array}{c}\text { Average annual } \\
\mathrm{P} \text { balance } \\
\mathrm{kg} \mathrm{ha}^{-1}\end{array}$ & 1971-1986 & 133.1 & 1.85 & -0.0034 & $0.83 * *$ \\
\hline & & 1971-1998 & 123.9 & 2.51 & 0.0032 & $0.98^{* *}$ \\
\hline & & 1971-2019 & 145.4 & 3.25 & -0.0025 & $0.99 * *$ \\
\hline
\end{tabular}

** - significant at the $P<0.01$ probability level

In Germany, since 1902, the fertilisation of agricultural crops with mineral and organic fertilisers has increased the concentration of mobile $\mathrm{P}_{2} \mathrm{O}_{5}$ in the soil up to six times. However, when they applied only NK fertilisers and had a negative $\mathrm{P}$ balance in the soil, the concentration of this element in the soil decreased more compared to the zero variant (Medinski et al., 2018). Another long-term experiment found that in unfertilised fields $\mathrm{P}$ was released from sparingly soluble forms for at least 30 years after the experiment was set up (Gransee, Merbach, 2000). In Romania, starting with 1986, when the usage of $P$ fertiliser decreased substantially, the area of low and very low $P$ content soils increased significantly (Dodociou et al., 2012).

Table 6. Influence of nitrogen $(\mathrm{N})$, phosphorus $\left(\mathrm{P}_{2} \mathrm{O}\right.$ concentration in the soil (2019)
Total phosphorus $\left(P_{\text {tol }}\right)$ concentration in the soil. According to the experimental data, due to longterm fertilisation both mobile $\mathrm{P}_{2} \mathrm{O}_{5}$ and $\mathrm{P}_{\text {tot }}$ concentrations in the soil increased, because part of $\mathrm{P}$, which is supplied as fertiliser, is chemically bound in the soil. That was confirmed by the data from long-term research conducted by Azevedo et al. (2018). The data of our experiment revealed that $\mathrm{P}_{\text {tot }}$ concentration in the soil was changing at a slower rate compared to changes of mobile $\mathrm{P}_{2} \mathrm{O}_{5}$ concentration (Table 6).

During the experimental period 1971-2019, the $\mathrm{P}_{\text {tot }}$ concentration in the plots not fertilised with $\mathrm{P}$ fertilisers ranged from $0.284 \%$ to $0.293 \%$. On average, having applied higher rates of $\mathrm{N}$ and $\mathrm{K}\left(\mathrm{N}_{216} \mathrm{~K}_{190}\right)$ fertilisers

\begin{tabular}{|c|c|c|c|c|}
\hline \multirow{5}{*}{$\mathrm{N}$} & \multirow{5}{*}{$\mathrm{P}_{2} \mathrm{O}_{5}$} & \multicolumn{3}{|c|}{ Average annual fertiliser rate $\mathrm{kg} \mathrm{ha}^{-1}$} \\
\hline & & \multicolumn{3}{|c|}{$\mathrm{K}_{2} \mathrm{O}$} \\
\hline & & 0 & 95 & 190 \\
\hline & & $\begin{array}{l}\mathrm{P}_{\text {tot }} \text { concentration }(\%) \\
\text { in 0-20 cm soil layer }\end{array}$ & & \\
\hline & & $\begin{array}{c}\mathrm{P}_{\text {tot }} \text { concentration in } 1971 \\
-0.301 \%\end{array}$ & & \\
\hline \multirow{3}{*}{0} & 0 & $0.290 \mathrm{a}$ & $0.293 \mathrm{ab}$ & $0.284 \mathrm{a}$ \\
\hline & 95 & $0.537 \mathrm{fg}$ & $0.492 \mathrm{ef}$ & $0.539 \mathrm{fg}$ \\
\hline & 190 & $0.725 \mathrm{k}$ & $0.686 \mathrm{ijk}$ & 0.664 hijk \\
\hline \multirow{3}{*}{108} & 0 & $0.357 \mathrm{bc}$ & $0.327 \mathrm{ab}$ & $0.334 \mathrm{ab}$ \\
\hline & 95 & 0.509 ef & $0.462 \mathrm{de}$ & $0.419 \mathrm{~cd}$ \\
\hline & 190 & $0.695 \mathrm{jk}$ & $0.702 \mathrm{jk}$ & $0.594 \mathrm{gh}$ \\
\hline \multirow{3}{*}{216} & & $0.280 \mathrm{a}$ & $0.358 \mathrm{bc}$ & $0.315 \mathrm{ab}$ \\
\hline & 95 & $0.519 \mathrm{ef}$ & $0.485 \mathrm{def}$ & $0.460 \mathrm{de}$ \\
\hline & 190 & $0.690 \mathrm{jk}$ & $0.614 \mathrm{hi}$ & $0.677 \mathrm{ijk}$ \\
\hline
\end{tabular}

Note. Different letters (a, b, c, etc.) indicate significant differences between the compared experimental applications at $P \leq 0.05$. 
annually but without $\mathrm{P}$ fertilisation $\left(\mathrm{P}_{0}\right)$, a slightly higher level of $\mathrm{P}_{\text {tot }}$ was detected in the $0-20 \mathrm{~cm}$ soil layer $-0.315 \%$, which was apparently influenced by higher amounts of plant residues left in the soil. Meanwhile, with the annual incorporation of $\mathrm{P}_{95}$ and $\mathrm{P}_{190}$, the $\mathrm{P}_{\text {tot }}$ in the soil during the whole experimental period increased significantly by $0.460 \%$ and $0.677 \%$, respectively. However, the highest $\mathrm{P}_{\text {tot }}$ content $(0.725 \%)$ was found in the soil after the application of $\mathrm{P}_{190}$ fertiliser rate but without $\mathrm{N}$ and $\mathrm{K}\left(\mathrm{N} \mathrm{K}_{0}\right)$ fertilisation. Anyway, most importantly, the total $\mathrm{P}$ concentration in the soil of plots not fertilised with $\mathrm{P}$ fertilisers hardly changed during 49 years. Similar results were obtained in Germany, where a 110-year crop fertilisation experiment showed a positive $\mathrm{P}$ balance in the soil with the $\mathrm{P}_{\text {tof }}$ concentration increasing up to two-fold compared to unfertilised fields (Medinski et al., 2018).

Long-term fertilisation of agricultural plants with mineral $\mathrm{P}$ fertilisers resulted in a strong and significant dependence $(r=0.89, P<0.01)$ of the $\mathrm{P}_{\text {tot }}$ concentration $(y ; \%)$ on the average annual $\mathrm{P}$ balance $\left(x ; \mathrm{kg} \mathrm{ha}^{-1}\right)$ in the $0-20 \mathrm{~cm}$ soil layer (Table 7). Therefore, the P unabsorbed by the plants could be converted to exchangeable and non-exchangeable forms.

Table 7. Relationship between total phosphorus $\left(\mathrm{P}_{\text {tot }}\right)$ concentration in the soil and $\mathrm{P}$ balance (1971-2019)

\begin{tabular}{|c|c|c|c|c|c|}
\hline \multirow[t]{2}{*}{$y$} & \multirow[t]{2}{*}{$x$} & \multicolumn{3}{|c|}{$\begin{array}{c}\text { Parameters of equation } \\
y=\mathrm{a}+\mathrm{b} x+\mathrm{cx}^{2}\end{array}$} & \multirow[t]{2}{*}{$R^{2}$} \\
\hline & & $\mathrm{a}$ & $\mathrm{b}$ & $\mathrm{c}$ & \\
\hline $\begin{array}{l}P_{\text {tot }} \text { concentration } \\
\text { in soil } \%\end{array}$ & $\begin{array}{c}\text { Average annual } \\
\mathrm{P} \text { balance } \\
\mathrm{kg} \mathrm{ha}^{-1}\end{array}$ & 0.266 & 0.0011 & -0.0000033 & $0.81 * *$ \\
\hline
\end{tabular}

** - significant at the $P<0.01$ probability level

Phosphorus leaching from the soil. Phosphorus not used in agricultural plant nutrition can contaminate surface waters and cause their eutrophication (Bergström et al., 2015). Although it is estimated that, due to low $P$ mobility in the soil, it leaches only about $1 \mathrm{~kg} \mathrm{ha}^{-1}$ per year (Glaesner et al., 2013). According to the experimental data, high concentration of mobile $\mathrm{P}_{2} \mathrm{O}_{5}$ in the soil significantly increase phosphorus leaching (Table 8 ).

The lowest average annual phosphate $\left(\mathrm{PO}_{4}^{3-}\right)$ concentration in lysimeter leachates was in the plots not fertilised with $\mathrm{P}$ fertilisers. In 1976-1998, only
$0.29-0.53 \mathrm{mg} \mathrm{L}^{-1}$ was detected, which corresponds to only $0.43-0.77 \mathrm{~kg} \mathrm{ha}^{-1}$ leaching of $\mathrm{P}_{2} \mathrm{O}_{5}$. During 1976 2019 , such $\mathrm{P}_{2} \mathrm{O}_{5}$ leaching was close but slightly higher $-0.82-0.90 \mathrm{~kg} \mathrm{ha}^{-1}$. Meanwhile, the annual fertilisation of agricultural crops with $\mathrm{P}_{190} \mathrm{~kg} \mathrm{ha}^{-1}$ and mobile $\mathrm{P}_{2} \mathrm{O}_{5}$ accumulation of $478-629 \mathrm{mg} \mathrm{kg}^{-1}$ in the soil resulted in $\mathrm{P}_{2} \mathrm{O}_{5}$ leaching of 4.15-5.51 kg ha-1 from the 0-40 cm layer of soil in 1976-1998 and 5.63-6.18 $\mathrm{kg} \mathrm{ha}^{-1}$ in 1976-2019 annually. This is eight to ten times more than in the plots not fertilised with $\mathrm{P}$.

Table 8. Influence of nitrogen $(\mathrm{N})$, phosphorus $\left(\mathrm{P}_{2} \mathrm{O}_{5}\right)$ and potassium $\left(\mathrm{K}_{2} \mathrm{O}\right)$ fertiliser rates and mobile $\mathrm{P}_{2} \mathrm{O}_{5}$ concentration in the soil on $\mathrm{P}$ leaching from $0-40 \mathrm{~cm}$ soil layer

\begin{tabular}{|c|c|c|c|c|c|c|c|c|}
\hline \multicolumn{3}{|c|}{$\begin{array}{l}\text { Average annual } \\
\text { fertiliser rate } \\
\mathrm{kg} \mathrm{ha}^{-1}\end{array}$} & \multicolumn{2}{|c|}{$\begin{array}{c}\text { Mobile } \mathrm{P}_{2} \mathrm{O}_{5} \text { concentration } \\
\text { in soil } \\
\mathrm{mg} \mathrm{kg}^{-1}\end{array}$} & \multicolumn{2}{|c|}{$\begin{array}{c}\text { Average annual } \\
\mathrm{PO}_{4}^{3-} \text { concentration } \\
\text { in lysimeter leachate } \\
\mathrm{mg} \mathrm{L}^{-1} \\
\end{array}$} & \multicolumn{2}{|c|}{$\begin{array}{c}\mathrm{P}_{2} \mathrm{O}_{5} \text { leached from soil } \\
\text { every year } \\
\mathrm{kg} \mathrm{ha}^{-1}\end{array}$} \\
\hline $\mathrm{N}$ & $\mathrm{P}_{2} \mathrm{O}_{5}$ & $\mathrm{~K}_{2} \mathrm{O}$ & 1998 & 2019 & $1976-1998$ & 1976-2019 & $1976-1998$ & 1976-2019 \\
\hline 0 & 0 & 0 & $55 \pm 5.6$ & $64 \pm 3.5$ & $0.53 \mathrm{a}$ & $0.62 \mathrm{a}$ & 0.77 & 0.90 \\
\hline 0 & 95 & 95 & $283 \pm 19.8$ & $335 \pm 12.1$ & $1.83 \mathrm{~b}$ & $2.38 \mathrm{e}^{\mathrm{a}}$ & 2.66 & 3.46 \\
\hline 108 & 0 & 95 & $56 \pm 8.5^{\circ}$ & $64 \pm 8.5$ & $0.30 \mathrm{a}$ & $0.58 \mathrm{a}$ & 0.44 & $\begin{array}{l}5.40 \\
0.84\end{array}$ \\
\hline 108 & 95 & 0 & $282 \pm 19.7$ & $321 \pm 12.7$ & $2.70 \mathrm{c}$ & $2.00 \mathrm{~b}$ & 3.93 & 2.90 \\
\hline 108 & 95 & 95 & $264 \pm 15.5$ & $327 \pm 11.3$ & $1.96 \mathrm{~b}$ & $1.86 \mathrm{~b}$ & 2.85 & 2.70 \\
\hline 0 & 190 & 190 & $629 \pm 17.0$ & $614 \pm 15.6$ & $3.01 \mathrm{~d}$ & $4.20 \mathrm{~d}$ & 4.38 & 6.10 \\
\hline 216 & 0 & 190 & $58 \pm 8.5$ & $63 \pm 9.9$ & $0.29 \mathrm{a}$ & $0.56 \mathrm{a}$ & 0.43 & 0.82 \\
\hline 216 & 190 & 0 & $478 \pm 14.1$ & $503 \pm 11.3$ & $2.86 \mathrm{~cd}$ & $4.25 \mathrm{~d}$ & 4.15 & 6.18 \\
\hline 216 & 190 & 190 & $484 \pm 11.3$ & $554 \pm 18.4$ & $3.79 \mathrm{e}$ & $3.87 \mathrm{f}$ & 5.51 & 5.63 \\
\hline
\end{tabular}

Note. Different letters (a, b, c, etc.) indicate significant differences between the compared experimental applications at $P \leq 0.05$.

The annual application of $\mathrm{P}_{95}$, i.e., the maximum allowed rate (40 $\left.\mathrm{kg} \mathrm{ha}^{-1} \mathrm{P}\right)$ according to $\operatorname{HELCOM}(2020)$ recommendations resulted in $\mathrm{P}_{2} \mathrm{O}_{5}$ leaching from 2.66 to $3.93 \mathrm{~kg} \mathrm{ha}^{-1}$ annually. According to the experimental data, the average $\mathrm{PO}_{4}^{3-}$ concentration in the soil significantly depended on the $\mathrm{P}_{2} \mathrm{O}_{5}$ concentration in the $0-20 \mathrm{~cm}$ soil layer. The dependence of $\mathrm{PO}^{3-}$ concentration in the soil solution on soil P content in 1976-1998 and 1976-2019 was described by the following regression equations: $y$ $=-0.31+0.012 \mathrm{x}-0.00011 \mathrm{x}^{2}(r=0.96, p<0.01)$ and $\mathrm{y}=0.21+0.052 \mathrm{x}+0.0000029 \mathrm{x}^{2}(r=0.98, p<0.01)$, respectively. The studies conducted in Western European countries show similar trends. In the UK, there was little $\mathrm{P}$ leaching from the soil observed when $\mathrm{P}$ concentration in the soil arable layer (according to Olsen) was less than $60 \mathrm{mg} \mathrm{kg}^{-1}$. As the mobile $\mathrm{P}_{2} \mathrm{O}_{5}$ concentration in the soil increased, its leaching also increased (Hesketh, Brookes, 2000). The studies in Germany also found a positive and significant correlation between the mobile $\mathrm{P}_{2} \mathrm{O}_{5}$ concentration in the soil arable layer and the annual $\mathrm{P}$ concentration in lysimeter leachates (Rupp et al., 2018).

Long-term fertilisation trials are important in assessing the long-term effects of fertilisers on soil and the efficiency of their use. In the course of such longterm trials, not only the generations of researchers change but also the goals, evaluation criteria and understanding. Fifty years ago, the prevailing opinion was that only well-cultivated P-rich soils could produce a good crop yield, which is why the aim was abundant fertilisation with P. At that time, $\mathrm{P}$ fertilisers were also cheaper, and less attention was paid to ecology. As show the results of the study, in 49 years, very high rates of $\mathrm{P}_{190}$ fertilisers increased the mobile $\mathrm{P}_{2} \mathrm{O}_{5}$ concentration in the $0-20 \mathrm{~cm}$ soil layer almost 10 times - from 57 to $554 \mathrm{mg} \mathrm{kg}^{-1}$.

However, from an ecological point of view, significantly higher $\mathrm{P}$ amounts from the $0-40 \mathrm{~cm}$ layer were leached out - the annual average of $5.97 \mathrm{mg} \mathrm{kg}^{-1}$, while only $0.85 \mathrm{mg} \mathrm{kg}^{-1}$ were leached out from the plots 
not fertilised with $\mathrm{P}$. Moreover, the $\mathrm{P}$ balance shows that at such a high rate of fertilisation about 131-160 kg $\mathrm{ha}^{-1} \mathrm{P}_{2} \mathrm{O}_{5}$ remains unassimilated by plants every year. Meanwhile, the $\mathrm{P}_{95}$ fertilisation rate, which is close to the rate prescribed by HELCOM and used in some European Union countries as the maximum rate limiting $\mathrm{P}$ for organic fertilisers $\left(40 \mathrm{~kg} \mathrm{ha}^{-1} \mathrm{P}=92 \mathrm{~kg} \mathrm{ha}^{-1} \mathrm{P}_{2} \mathrm{O}_{5}\right)$ was also rather high, because the annual balance of $\mathrm{P}^{2}$ obtained was higher - 45-68 kg ha-1 $\mathrm{P}_{2} \mathrm{O}_{5}$. Therefore, such an annual rate could only be applied in individual years and for more demanding plants, and for the majority of plants the $\mathrm{P}_{30}-\mathrm{P}_{60}$ rates would suffice.

Importantly, this long-term study established the dependence of $\mathrm{P}$ fertiliser uptake on mineral NPK fertiliser rates, and a relationship between the total $\mathrm{P}_{\text {to }}$ and mobile $\mathrm{P}_{2} \mathrm{O}_{5}$ concentrations in the soil and the $\stackrel{\mathrm{P}}{\mathrm{P}}$ balance was found.

\section{Conclusions}

1. The concentration of mobile phosphorus $\left(\mathrm{P}_{2} \mathrm{O}_{5}\right)$ in the 0-20 cm layer of a sandy loam EpicalcariEndocalcari-Endohypogleyic Luvisol before the experiment was $64 \pm 11.4 \mathrm{mg} \mathrm{kg}^{-1}$, and after 49 years it was found different against the background of nitrogen $(\mathrm{N})$ and potassium $(\mathrm{K})$ fertilisers in different P-fertilised plots: $62-71 \mathrm{mg} \mathrm{kg}^{-1}$ without P, 280-351 mg kg-1 with annual $\mathrm{P}_{95}$ fertilisation and 503-614 mg kg-1, or 10 times higher, with $\mathrm{P}_{100}$. Under the influence of $\mathrm{P}$ fertilisers, the mobile $\mathrm{P}_{2} \mathrm{O}_{5}$ concentration in the soil increased significantly during the first two decades compared to the later years.

2. Due to fertilisation with $P$, the total phosphorus $\left(\mathrm{P}_{\text {tot }}\right)$ concentration in the soil increased. If before the start of the trial it was $0.301 \pm 0.043 \%$, then after 49 years it was $0.280-0.357 \%$ in P-unfertilised plots, $0.509-0.537 \%$ in the plots fertilised with $\mathrm{P}_{95}$ annually and $0.690-0.725 \%$ in the plots fertilised with $\mathrm{P}_{190}$.

3. The $P$ balance showed that after 49 years of annual applications of $\mathrm{P}_{95}$ to agricultural crops, 45.4-68.7 $\mathrm{kg} \mathrm{ha}^{-1}$ was incorporated and, when $\mathrm{P}_{190}$ was applied, $131.0-160.3 \mathrm{~kg} \mathrm{ha}^{-1}$ was incorporated in excess of the need for this element by plants. The most inefficient uptake - 5.4-11.4\% P - was observed after annual applications of $\mathrm{P}_{190}$ without the use of $\mathrm{N}$ and $\mathrm{K}$ fertilisers. The uptake increased to $27.3-32.6 \%$ when $\mathrm{N}_{216} \mathrm{~K}_{190}$ fertiliser was applied together with $\mathrm{P}_{95}$.

4. With increasing rates of $P$ fertilisers, mobile $\mathrm{P}_{2} \mathrm{O}_{5}$ leaching from the $0-40 \mathrm{~cm}$ soil layer increased. Without $P$ application, its annual leaching was as follows: in 1976-1998 it was $0.43-0.77 \mathrm{~kg} \mathrm{ha}^{-1}$, and in 1976-2019 $-0.82-0.90 \mathrm{~kg} \mathrm{ha}^{-1}$. Annual fertilisation with $\mathrm{P}_{95}$ resulted in the leaching of 2.66-3.93 and $2.70-3.46 \mathrm{~kg} \mathrm{ha}^{-1}$, and with $\mathrm{P}_{190}$ the leaching amounted to $4.15-5.51$ and 5.63$6.18 \mathrm{~kg} \mathrm{ha}^{-1}$, respectively.

5. The long-term study established a significant relationship $\left(r=0.96^{* *}\right)$ between $\mathrm{P}$ fertiliser uptake and NPK fertiliser rates, between mobile $\mathrm{P}_{2} \mathrm{O}_{5}$ concentration in the soil and $\mathrm{P}$ balance $(r=0.99 * *)$ and between $\mathrm{P}_{\text {tot }}$ concentration in the soil and $\mathrm{P}$ balance $\left(r=0.90^{* *}\right)$.

6. Long-term analysis revealed that $\mathrm{P}_{95}$ fertilisation rate, which is close to HELCOM (40 kg ha-1 $\mathrm{P}=92 \mathrm{~kg} \mathrm{ha}^{-1} \mathrm{P}_{2} \mathrm{O}_{5}$ ) rate, was too high, as it exceeded the need for this element for plants. Therefore, it is recommended to apply such annual rate only to highly demanding plants and for the majority of the plants $\mathrm{P}_{30}-$ $\mathrm{P}_{60}$ rates would be sufficient.

Received 24092020

Accepted 16062021

\section{References}

Ågren G. J., Wetterstedt J. A. M., Bilberger M. F. K. 2012. Nutrient limitation on terrestrial plant growth - modeling the interaction between nitrogen and phosphorus. New Phytologist Fcolnoical Stachinmetry and Glohal Change $\mathrm{n}$. 953-960. https://doi.org/10.1111/j.1469-8137.2012.04116.x

Arheimer B., Dahne J., Donnelly C. 2012. Climate change impact on riverine nutrient load and land-based remedial measures of the Raltic Sea Action Plan Amhio, 41: 600-612. https://doi.org/10.1007/s13280-012-0323-0

Azevedo K. P., Salcedo I. H., Lima P. A., Fraga V. S., Lana R. M. Q. 2018. Mobility of phosphorus from organic and inorganic source materials in sandy soil. International Journal of Recycling of Organic. Waste in Agriculture. 7: 153-163. https://doi.org/10.1007/s40093-018-0201-2

Baigys $\mathrm{G}$., Gaigalis K. 2012. Intluence of land tillage methods on drainage runoff and nitrogen migration. Vandens ūkio inžinerija, 40 (60): 83-93 (in Lithuanian). https://hdl.handle.net/20.500.12259/84489

Barberis E., Ajmone Marsan F., Scalenghe R., Lammers A., Schwertmann U., Edwards A. C., Maguire R., Wilson M. J., Delgado A., Torrent J. 1995. European soils overfertilized with phosphorus. Part 1 Rasic nronerties Fertilizer Research, 45 (3): 199-207. https://doi.org/10.1007/BF00748590

Benton J. Jr. 2012. Plant Nutrition and Soil Fertility ( $\left.2^{\text {nd }} e d.\right)$. CRC Press, p. 5-167. http://www.taylorandfrances.com

Bergström L., Kirchmann H., Djodjic F., Kyllmar L., Ulen B., Liu J., Andersson H., Aronnson H., Börjesson G., Kynkääniemi P., Swanbäck A., Villa A. 2015. Turnover and losses of phosphorus in Swedish agricultural soils: longterm changes, leaching trends, and mitigation measures. Inurnal of Fnvirnnmental Muality 44 (0): 512-523. https://doi.org/10.2134/jeq2014.04.0165

Blake L., Mercik S., Koerchens M., Moskal S., Poulton P. R. Goulding K. W. T., Weigel A., Powlson D. S. 2000 Phosphorus content in soil, uptake by plants and balance in three European long-term field experiments. Nutrient Cycling in A oroesnsvstems 56 (3) $\cdot 263-775$. https://doi.org/10.102̌3/A:1009841603931

Braun S., Warrinner K., Börjesson G., Ulen B., Smolders E., Gustafsson P. 2019. Assessing the ability of soil tests to estimate labile phosphorus in agricultural soils: evidence from isntonic exchange Tenderma 337. 350-358. https://doi.org/10.1016/j.geoderma.2018.09.048

Buczko U., Van Laak M., Eichler-Löbermann B., Gans W., Merbach I., Panten K., Peiter E., Reitz T., Spiegel H., Von Tucher S. 2018. Re-evaluation of the yield response to phosphorus fertilization based on meta-analyses of lono-term field exneriments Amhin 47 (1): 550-561. https://doi.org/10.1007/s13280-017-0971-1

Communication from the commission to the European parliament, the European council, the council, the European economic and social committee the committee of the regions. 2019. The European Green Deal. https://eur-lex. europa.eu/resource.html?uri=cellar:b828d165-1c22-11 ea8c1f-01aa75ed71a1.0002.02/DOC 1\&format=PDF

Communication from the commission to the European parliament, the European council, the council, the European economic and social committee the committee of the regions. 2020. EU Biodiversity Strategy for 2030. https://eur-lex. europa.eu/resource.html?uri=cellar:a3c806a6-9ab3-11 ea9d2d-01aa75ed71a1.0001.02/DOC 1\&format=PDF

Cordell D., Drangert J., White G. 2009. The story of phosphorus: global food security and fond for thought Geoderma 177: 270-279. https://doi.org/10.1016/j.gloenvcha.2008.10.009

Dodociou A. M., Mocanu K., Dobre M. 2012. 'The long term evaluation of phosphates from the Cambic Chernozem at ARDS Carakal Romania Iournal of $I$ ife Sciences 6.557562. https://doi.org/10.17265/1934-7391/2020.01.001

Ekholm P. 'lurtola E. Grönroos J., Seuri P., Ylivainio K. 2005. Phosphorus loss from different farming systems estimated from soil surface phosphorus balance. Agriculture, Fonsystems and Fnvirnnment 110 (3-4) 2.66-278. https://doi.org/10.1016/j.agee.2005.04.014

From Farm to Fork: Uur food, our health, our planet, our future. 2020. European Commission. https://ec.europa.eu/ commission/presscorner/detail/en/fs_20_908

Glaesner N., Kjaegaard C., Rubaek G. H., Magid J. 2013. Relation between soil $\mathrm{P}$ test values and mobilization of dissolved and particulate $\mathrm{P}$ from the plough layer of typical Danish soils from a long-term field experiment with applied 
P fertilizers. Soil IJse and Management, 29 (3): 297-305. https://doi.org/10.1111/sum.12060

Gransee A., Merbach W. 2000. Phosphorus dynamics in a longterm P fertilization trial on Luvic Phaeozem at Halle. Journal of Plant Nutrition and Soil Science 163 (4) $353-357$ httns://doi.org/10.1002/1522-2624(200008)163:4<353:: AID-JPLN353>3.0.CO;2-B

HELCOM. 2020. The Baltic Marine Environment Protection Commission. Input of nutrients: potential to reduce input from point sources. ACTION project. https://helcom.fi/wpcontent/uploads/2020/10/Inputs-of-nutrients-potential-toreduce-input-from-point-sources-ACTION-WP4.pdf

Hesketh N., Brookes P. C. 2000. Development of an Indicator for risk of phosphorus leaching. Journal of Environmental Ouality $29(1) \cdot 105-110$

https://doi.org/10.2134/jeq2000.00472425002900010013x

Hill T., Levicki P. 2005. Statistics: Methods and Applications. StatSoft Inc., $800 \mathrm{p}$.

Johnston A. E., Poulton P. R. 2018. The importance of longterm experiments in agriculture: their management to ensure continued crop production and soil fertility; the Rothamsted experience. Furnnean Iournal of Soil Science, 69 (1): 112-125. https://doi.org/10.1111/ejss.12521

Johnston A. E., Poulton P. R., Fixen P. E., Curtin D. 2014. Phosphorus: its efficient use in agriculture. Advances in Agronomy. 123: 177-228 https://doi.org/10.1016/B978-0-12-420225-2.00005-4

Jordan-Meille L., Kubæk G. H., Ehlert P. A. I., Genot V., Hofman G., Goulding K., Recknagel J., Provolo G., Barraclough P. 2012. An overview of fertilizer-P recommendations in Europe: soil testing, calibration and fertilizer recommendations. Soil Use and Management, $28(4): 419-435$ https://doi.org/10.1111/j.1475-2743.2012.00453.x

López-Arredondo D. L., Leyva-Gonzálex M. A., GonzálezMorales S. I., López-Bucio J., Herrera-Estrella L. 2014. Phosphate nutrition: improving low-phosphate tolerance in crons. Annual Review of Plant Biolngv. 65: 95-123 https://doi.org/10.1146/annurev-arplant-050213-035949

Kim K., Kim B., Eum J., Seo B., Shope C. L., Peiffer S. 2018 Impacts of land use change and summer monsoon on nutrients and sediment exnorts from an agricultural catchment. Water, 10 (5): 544. https://doi.org/10.3390/w10050544

Management of agroecosystem components. Results of long-term agrochemical experiments. 2010 / compiled by Tripolskaja L. et al. Lithuanian Research Centre for Agriculture and Forestry, 568 p. (in Lithuanian).

Medinski T., Freese D., Reitz T. 2018. Changes in soil phosphorus balance and phosphorus-use efficiency under long-term fertilization conducted on agriculturally used Chernozem in Germany. Canadian Inurnal of Soil Science, 98 (4): 650-662. https://doi.org/10.1139/cjss-2018-0061
Raudonius S. 2017. Application of statistics in plant and crop research: important issues 7emdirhyste-A oriculture 104 (4): 377-282. https://doi.org/10.13080/z-a.2017.104.048

Rupp H., Meissner R., Leinweber P. 2018. Plant available phosphorus in soil as predictor for the leaching potential: insights from long-term lysimeter studies Amhio, 47 (1): 103-113. https://doi.org/10.1007/s13280-017-0975-x

Scholz R. W., UIrich A. E., Eilitta M., Roy A. 2013. Sustainable use of phosphorus: a finite resource. Science of the Total Fnvirnnment 461-46) · 799-803 https://doi.org/10.1016/j.scitotenv.2013.05.043

Schoumans U. F., Bouraou1 F., Kabbe C., Uenema O., van Dijk K. C. 2015. Phosphorus management in Europe in a changing world Amhin 44.180-19? https://doi.org/10.1007/s13280-014-0613-9

Syers J. K., Johnston A. E., Curtin D. 2008. Etticiency of soil and fertilizer phosphorus use. FAO Fertilizer and Plant Nutrition Bulletin 18, 108 p. http://www.fao.org/3/a-a1595e.pdf

Thodsen H., Farkas C., Chormanski J., Trolle D., BliccherMathiesen G., Grant A., Engelbretsen A., Kardel I., Andersen H. E. 2017. Modelling nutrient load changes from fertilizer application scenarios in six catchments around the Raltic Sea A griculture 7.41 https://doi.org/10.3390/agriculture7050041

Tóth G., Guicharnaud R. A., T'óth B., Hermann T. 2014. Phosphorus levels in croplands of the European Union with implications for P fertilizer use. European Journal of A oronomy 55. 45-5? https://doi.org/10.1016/j.eja.2013.12.008

Vaišvila Z. 19Y6. Dırvożemı mıneralınıo azoto, judriụu fosforo ir kalio vaidmuo žemès ūkio augalu mityboje: habilitacinis darbas. Lithuanian Institute of Agriculture, 206 p. (in Lithuanian).

Veneklaas E. J., Lambers C. E., Bragg J., Finnegan P. M., Lovelock C. E. Plaxton W. C., Price Ch. A., Schneible W. R., Shane M. W., White P. J., Raven J. A. 2012. Opportunities for improving phosphorus-use efficiency in crop plants. New Phytolngist $195(3) \cdot 306-370$ https://doi.org/10.1111/j.1469-8137.2012.04190.x

Withers P. J. A., Van Dijk K. C., Neset I. S. S., Nesme T., Oenema O., Rubæk G. H., Schoumans O. F., Smith B., Pellerin S. 2015. Stewardship to tackle global phosphorus inefficiency the rase of Furope. AMBIO, 44 (2): 193-206. https://doi.org/10.1007/s132

WRB. 2015. World reterence base for soil resources. World soil resources reports No. 106. http://www.fao.org/3/a-i3794en.pdf

Перегудов В. Н. и др. 1976. Проведение многофакторных опытов с удобрениями и математический анализ их результатов [Conducting multifactorial experiments with fertilizers and mathematical analysis of their results]. Москва, 112 с. (in Russian).

Шилова Е. И. 1955. Метод получения почвенного раствора в природных условиях [Method for getting soil solution in natural conditions]. Почвоведение, 11: 48-61 (in Russian).

\title{
Ilgalaikio tręšimo įtaka fosforo dinamikai dirvožemyje
}

\author{
J. Arbačauskas, A. Masevičienė, G. Staugaitis, L. Žičkienè, D. Šumskis, Z. Vaišvila
}

Lietuvos agrarinių ir miškų mokslų centras

\section{Santrauka}

Ilgalaikis žemės ūkio augalų tręšimo eksperimentas vykdytas 1971-2019 m. Vidurio Lietuvoje, smèlingo lengvo priemolio sekliai karbonatingame giliau glejjiškame išplautžemyje. Tyrimo tikslas - nustatyti ilgalaikio mineralinių fosforo $(\mathrm{P})$ trąšu naudojimo ir ju sąveikos su azoto $(\mathrm{N})$ bei kalio $(\mathrm{K})$ trąšomis itaką fosforo trąšu pasisavinimui, judriojo $\mathrm{P}_{2} \mathrm{O}_{5}$ koncentracijai bei balansui dirvožemyje ir įvertinti jo ryšị su $\mathrm{P}$ išplovimu iš smèlingo priemolio. Tyrimo duomenimis, po 49 metu skirtingais NPK trąšu deriniais tręštuose laukeliuose judriojo $\mathrm{P}_{2} \mathrm{O}_{5}$ dirvožemio 0-20 cm sluoksnyje nustatyta nevienodai: netręšus fosforu $\left(\mathrm{P}_{0}\right)-62-71 \mathrm{mg} \mathrm{kg}^{-1}$, kasmet patręšus $\mathrm{P}_{05}^{2}-280-351 \mathrm{mg}$ $\mathrm{kg}^{-1}$, patręšus $P_{190}-503-614 \mathrm{mg} \mathrm{kg}^{-1}$, arba 10 kartų daugiau nei netręšus fosforo trąšomis. Dèl fosforo trąšų itakos taip pat didejo suminio fosforo koncentracija dirvožemyje. Fosforo balansas parodè, kad žemès ūkio augalus 49 metus kasmet tręšiant $P_{95}$, $P$ buvo ịterpta $45,4-68,7 \mathrm{~kg} \mathrm{ha}^{-1}$, o $P_{190}-131,0-160,3 \mathrm{~kg} \mathrm{ha}^{-1}$ daugiau nei yra šio elemento poreikis augalams. Augalai neefektyviausiai $(5,4-11,4 \%) \mathrm{P}$ pasisavino kasmet tręšiant $\mathrm{P}_{190}$ ir nenaudojant azoto bei kalio trąšų. Pasisavinimas padidejo iki 27,3-32,6 \%, kai su $\mathrm{P}_{95}$ buvo įterpiama $\mathrm{N}_{216} \mathrm{~K}_{190}$ trąšų. Didinant fosforo trąšų normas, $\mathrm{P}_{2} \mathrm{O}_{5}$ išplovimas iš dirvožemio $0-40 \mathrm{~cm}$ sluoksnio didejjo.

Tyrimo metu nustatytas esminis priklausomumas tarp fosforo trąšų pasisavinamumo ir NPK trąšų normų, judriojo $\mathrm{P}_{2} \mathrm{O}_{5}$ koncentracijos dirvožemyje ir $\mathrm{P}$ balanso, suminio fosforo koncentracijos dirvožemyje ir $\mathrm{P}$ balanso.

Reikšminiai žodžiai: NPK tręšimas, balansas, judrusis fosforas, išplovimas. 